\title{
REVIEW
}

Open Access

\section{Neurological manifestations and neuroimaging findings in patients with SARS-CoV2-a systematic review}

Nikita Mohan ${ }^{1}$, Muhammad Ali Fayyaz ${ }^{2}$, Christopher del Rio ${ }^{3}$, Navpreet Kaur Rajinder Singh Khurana ${ }^{4^{*}}$ (D), Sampada Sandip Vaidya ${ }^{5}$, Esteban Salazar ${ }^{3}$, John Joyce ${ }^{6}$ and Amrat Ayaz Ali $^{7}$

\begin{abstract}
Background: The COVID-19 pandemic has drastically affected everyone in a hit or miss manner. Since it began, evidence of the neuro-invasive potential of the virus has been intensifying significantly. Several pathways have been hypothesized to elucidate the neurotropic nature of SARS-CoV2. It is the need of the hour to collect vital information.
\end{abstract}

Objective: To evaluate and correlate the neuro-radiological and neurological manifestations in patients diagnosed with SARS-CoV2.

To identify neuro-invasive pathways of COVID infection.

Methods: Relevant studies were identified through four databases—-the Cochrane Library, PubMed, Science Direct, and Web of Science. These were searched using relevant keywords-"COVID-19," "SARS-CoV2," "neurological manifestations," "neuroimaging," "CT," and "MRI." Relevant articles were screened according to a pre-defined inclusion and exclusion criteria from December 2019 to August 2020.

Results: Our review included a total of 63 full text publications with 584 patients, composed mainly of observational studies, case reports, and case series. The most common neurological manifestations associated with COVID-19 were altered mental status, stroke, and paralysis. About $17.85 \%$ patients who underwent neuroimaging were found to be having ischemic changes suggestive of a stroke. This was followed by hemorrhagic changes as the second most common finding. The most commonly involved vessel was the Middle Cerebral Artery. Besides stroke, we found that SARS-CoV2 could be the cause for new-onset seizures, Guillain-Barre Syndrome, encephalitis, and many other severe neurological diseases.

Conclusion: The information that we have obtained so far will prove dynamic to healthcare providers working against the COVID-19 pandemic. It is necessary to be aware of these atypical neurological findings for the early diagnosis and treatment of COVID-19 infected patients. However, to completely understand the connection between SARS-CoV2 and the nervous system, further research is necessary.

Keywords: SARS-CoV 2, Stroke, Neuro-invasive, COVID-19, Neuroimaging

\footnotetext{
* Correspondence: rhythmkhurana@gmail.com

${ }^{4}$ Indira Gandhi Government Medical College \& Mayo Hospital, Nagpur,

Maharashtra, India

Full list of author information is available at the end of the article
}

\section{Springer Open}

(c) The Author(s). 2021 Open Access This article is licensed under a Creative Commons Attribution 4.0 International License, which permits use, sharing, adaptation, distribution and reproduction in any medium or format, as long as you give appropriate credit to the original author(s) and the source, provide a link to the Creative Commons licence, and indicate if changes were made. The images or other third party material in this article are included in the article's Creative Commons licence, unless indicated otherwise in a credit line to the material. If material is not included in the article's Creative Commons licence and your intended use is not permitted by statutory regulation or exceeds the permitted use, you will need to obtain permission directly from the copyright holder. To view a copy of this licence, visit http://creativecommons.org/licenses/by/4.0/. 


\section{Introduction}

The infamous COVID-19 pandemic has drastically involved everyone in a hit or miss manner. The world is currently fighting against a highly infectious novel coronavirus, known as SARS-CoV2. What began as an outbreak of pneumonia in Wuhan, China, has rapidly engulfed the entire world [1]. As of August 31, 2020, this virus has infected approximately 25 million people and caused 844 thousand deaths globally [2]. The pandemic has posed severe challenges to public health, and the medical community continues to struggle in hitherto mysterious zones, especially in terms of reliable therapeutic interventions. In one study, health care providers utilized extracorporeal membrane oxygenation (ECMO) for patients with acute respiratory distress syndrome secondary to COVID-19, although early reports seem to have a high mortality rate due to devastating neurological insult [3].

Though the respiratory symptoms are the most common, there have been studies which highlight the potential neurotropism of the virus. The incubation period of COVID-19 infected patients, whether asymptomatic or possessing wide spread signs and symptoms, varies from 2 to 11 days with an approximate mortality rate of $2-4 \%$ [4]. In an observational study in Wuhan, $36.4 \%$ of the patients had neurological involvement such as impaired consciousness, acute cerebrovascular events, headache, seizure, hyposmia, and hypogeusia [5]. There have also been several reports on patients presenting with neurological involvement as the initial symptoms [6, 7].

This initial data reflects that the brain seems to be a target organ for various infections and critical diseases, either due to direct insult or through secondary involvement. The peripheral nervous system (PNS) is also particularly susceptible during infection-related immunemediated diseases [8].

Even though there is extensive data on the respiratory involvement of SARS-CoV2, documentation of its neurological aspect has been limited to observational studies and case reports. There is a further lack of information on the neuroimaging findings of COVID-19. In this rapidly evolving situation, it has become essential for healthcare providers to stay updated on the various atypical presentations of SARS-CoV2 and keep in mind COVID-19 as a potential diagnosis when encountering such cases. Therefore, we performed a comprehensive literature search in this systematic review to ascertain the different neurological manifestations and neuroimaging findings linked with COVID-19 infection.

\section{Objective}

To evaluate and correlate the neuro-radiological and neurological manifestations in patients diagnosed with SARS-CoV2.
To identify neuro-invasive pathways of COVID infection.

\section{Methods}

A comprehensive search of the literature was performed from the following databases: PubMed, Web of Science, Cochrane Library, and Science Direct. The following search terms were used in combination with the Boolean operators AND and OR; "COVID-19," "SARS-CoV2," "neurological manifestations," "neuroimaging," "MRI," and "CT." We selected for analysis only articles in which the title and abstract contained the aforementioned search terms. In an initial screen, we excluded articles which were duplicates, and those in which title and abstract were not relevant to our search terminology. Of the remaining studies, screening was done based on the full text of the article under the following inclusion criteria: (1) Studies reporting patients with laboratory confirmation of SARS-CoV2, (2) case reports, case series, cohort studies, and case-control studies, (3) studies in which subjects were above the age of 18 , (4) studies containing neuroimaging (CT or MRI) of the brain, (5) studies performed between December 2019 and August 2020. The exclusion criteria were as follows: (1) reviews, editorials, or commentaries. (2) Studies in which subjects were in the pediatric age group, were pregnant, or had prior neurological conditions. (3) Studies with no neurological evaluation, (4) studies published in any language other than English, without available English translations. The articles were screened in their entirety, by two independent readers, in each of the aforementioned scientific databases, to determine eligibility for inclusion. Discrepancies were discussed among all authors, and a collective effort was undertaken to resolve them.

The search strategy and article selection process are depicted in the flowchart in Fig. 1 as per the PRISMA statement.

\section{Results}

Through the search strategy, we identified 63 articles with neurological and neuroimaging manifestations in patients infected with COVID-19. We included 584 patients who presented with neurological manifestations and underwent different neuroimaging modalities. The age of patients ranged from 24-88 years.

In terms of neuroimaging findings (Table 1), among these 63 articles, 584 patients underwent neuroimaging. Four hundred and twenty eight $(67.61 \%)$ patients that underwent neuroimaging did not have any abnormality on CT or MRI. For the remaining 156 patients, neuroimaging findings were in descending order as follows: ischemic changes (17.85\%), with the middle cerebral artery (MCA) being the most frequent anatomical location; hemorrhagic changes (6.31\%), diffuse edema 


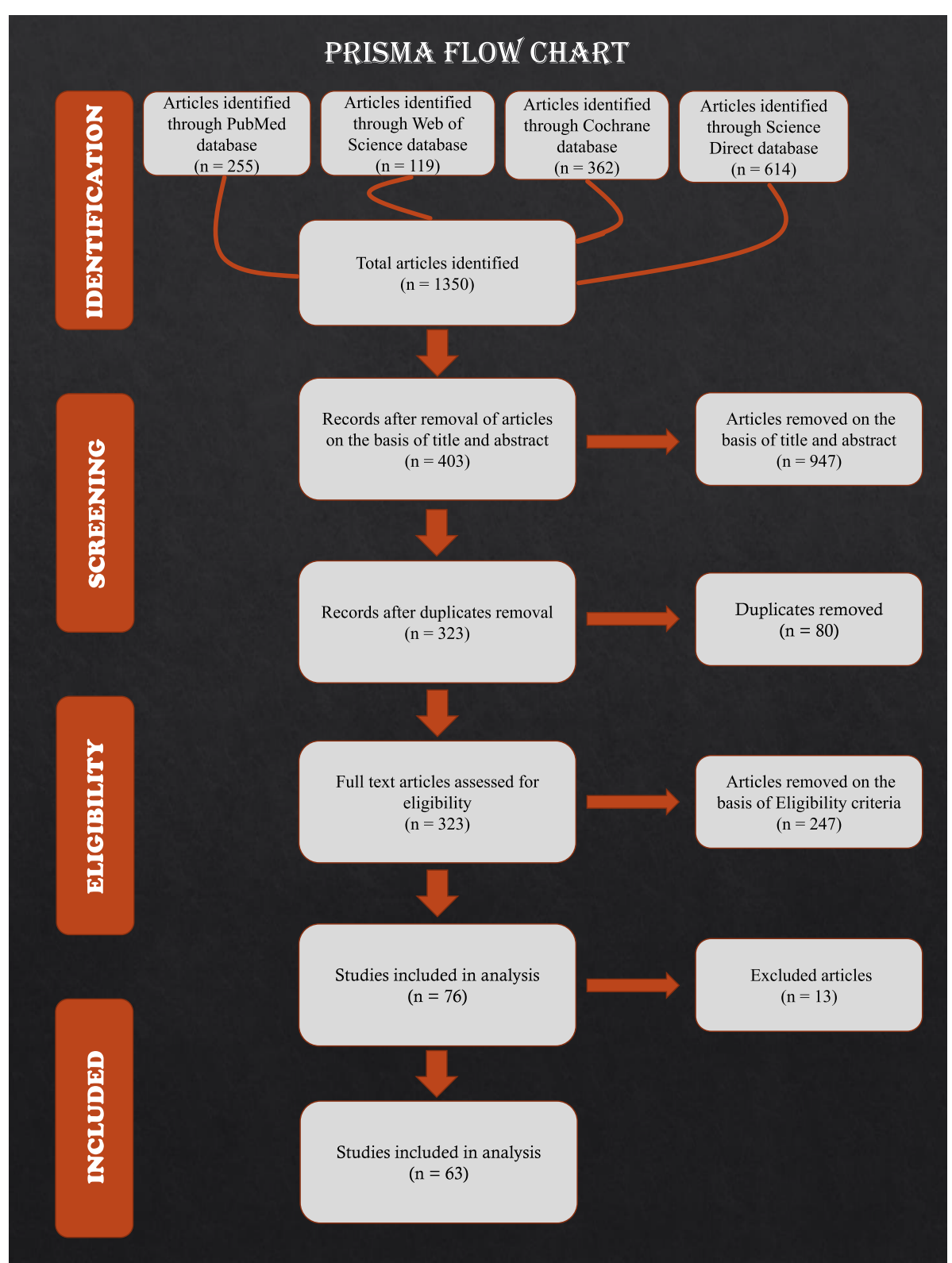

Fig. 1 PRSIMA flow chart summarizing search strategy for the articles included in the study

(1.57\%), encephalitis (1.57\%), herniation (with uncal and subfalcine as the most common) (1.26\%), venous thrombosis $(0.7 \%)$, atrophy $(0.4 \%)$, inflammatory process $(0.4 \%)$, and constriction $(0.4 \%)$. The absence of flow and signal changes was $0.3 \%$ each. The least common findings were acute myelitis, high-grade glioma, calcification of the proximal left internal carotid artery (ICA), a demyelinating lesion in left temporal and right occipital lobes, dissection of the left vertebral artery, and small-vessel disease comprised the remaining $0.6 \%$ (0.1\% each) (Fig. 2).

Out of the 157 distinct neurological manifestations presented in the 63 articles (Table 2), we were able to identify 5 possible groups. Patients were only included once per group. In order of prevalence: altered mental status (52.5\%), sensory alterations (19.7\%), motor alterations (17.7\%), others (5.5\%), and seizures (4.6\%) (Fig. 3). Certain articles with a larger patient population did not specify its prevalence for the different neurological manifestations. The only group with a female predominance was sensory alterations (51.7\%). No group had a defined male predominance. Altered mental status and others had a greater representation of un-specified sex (79.8\% and 80\% respectively) (Fig. 4).

\section{Discussion}

Since the outbreak of the SARS-CoV2 virus in December 2019, the majority of research has been 
Table 1 Reported studies on COVID-19 patients with neurological manifestations with positive findings on major imaging modalities

\begin{tabular}{lll}
\hline Article name & Imaging moda \\
\hline 1 & $\begin{array}{l}\text { A case of COVID-19 respiratory IIIness with } \\
\text { Subsequent seizure and hemiparesis [9] }\end{array}$ & CT-head \\
2 & $\begin{array}{l}\text { A case series of devastating intracranial } \\
\text { hemorrhage during venovenous extracorporeal } \\
\text { membrane oxygenation for COVID-19 [3] }\end{array}$ & CT-head \\
\end{tabular}

3 A first case of meningitis/encephalitis associated MRI — brain with SARS-coronavirus-2 [10]

4 Acute abducens nerve palsy in a patient with the novel coronavirus disease (COVID-19) [11]

5 Acute disseminated encephalomyelitis after SARS-CoV-2 infection [12]

6 Acute myelitis as a neurological complication of COVID-19: a case report and MRI findings [13]

7 Acute polyradiculoneuritis with locked-in syn- MRI—spine drome in a patient with COVID-19 [14]

8 Acute profound sensorineural hearing loss after MRI—brain COVID-19 pneumonia [15]

9 Basal ganglia involvement and altered mental status: a unique neurological manifestation of coronavirus disease 2019 [16]

10 Bilateral posterior cerebral artery territory infarction in a SARS-Cov-2 infected patient: discussion about an unusual case [17]

11 Bilateral trochlear nerve palsy due to cerebral vasculitis related to COVID-19 infection [18]

12 Cerebral microhemorrhage and purpuric rash in MRL-brain COVID-19: the case for a secondary microangiopathy [19]

13 Cerebral nervous system vasculitis in a COVID19 patient with pneumonia [20]

14 Cerebral venous thrombosis: a typical presentation of COVID-19 in the young [21]
Gadolinium-enhanced MRI—spine

\author{
CT-head \\ MRI-brain \\ MRI—brain \\ MRI—brain
}

MRL_brain
MRL_brain and spine

CT—headMRI—brain

CT-head MRI—brain

\section{Neuroimaging findings}

Subcortical hypoattenuation with sulcal effacement in the left occipital and posterior parietal lobes suggestive of ischemic changes

Multicompartment intracranial hemorrhage with marked diffuse edema and secondary infarction of the left anterior and posterior cerebral artery territories due to vascular compression Multifocal intracerebral hemorrhage $(\mathrm{ICH})$ with left hemispheric lobar hemorrhage and right cerebellar hemorrhage

Small left frontal cortical subarachnoid hemorrhage (SAH)

Diffusion weighted images (DWI) showed hyperintensity along the wall of inferior horn of right lateral ventricle.

Fluid-attenuated inversion recovery (FLAIR) images showed hyperintense signal changes in the right mesial temporal lobe and hippocampus - suggestive of right lateral ventriculitis and encephalitis.

Denervation of CN VI- as evident by hyperintensity on T2 weighting of atrophic left lateral rectus muscle

6 enhancing lesions, most with ring enhancement and some with nodular enhancement

Hyperintense signal of the optic nerves bilaterally Hyperintense spindle-like T8 lesion

Extensive diffuse hyperintense signal of the gray matter of cervical, dorsal, and lumbar regions of the spinal cord

Mild enlargement and swelling of the cervical cord

Areas of restricted diffusion on DWI and apparent diffusion coefficient (ADC)

Massive symmetrical contrast enhancement of the spinal nerve roots at all levels of the spine including the cauda equina

Pronounced contrast enhancement in the right cochlea and a partially decreased fluid signal in the basal turn of the right cochlea Adjacent to the temporal bone, meningeal contrast enhancement was seen at the base of the right temporal lobe Signs of an inflammatory process in the cochlea

$B / L$ basal ganglia hyper-density suggestive of subacute hemorrhagic event

Involvement of basal ganglia in subacute bleeding

$B / L$ and asymmetric acute occipito-temporal infarction of the posterior cerebral arteries (PCA) with occlusion of P3 segments Hemorrhagic transformation of the previous lesions

Signs of vasculitis of the vertebrobasilar system Inflammatory signs in the periaqueductal region, along the topography of the trochlear nuclei

Multiple areas of micro-hemorrhage throughout the corpus callosum, B/L juxtacortical white matter, basal ganglia, cerebellum, and brain- stem, without clear asymmetry

Discrete areas of FLAIR hyperintensity correlating with some of the larger areas of SWI changes suggesting larger macro-hemorrhage Areas of diffusion restriction

Cortical-subcortical blood-related hyperdensities in the right occipital lobes and B/L fronto-parietal

Signal restriction of the cortex in a parietal and parieto-occipital region and at the pons level suggestive of subacute phase of cortical inflammation and ischemia

Left temporoparietal hemorrhagic venous infarct with edema and mass effect with $5 \mathrm{~mm}$ rightward shift

Hyperintense DWI signal of the left temporoparietal hemorrhagic infarct with mass effect and effacement of the left lateral and third ventricle with $4 \mathrm{~mm}$ rightward shift Absence of flow in the sigmoid sinus, left transverse and internal jugular vein (IJV) secondary to venous thrombosis 
Table 1 Reported studies on COVID-19 patients with neurological manifestations with positive findings on major imaging modalities (Continued)

\begin{tabular}{|c|c|c|c|}
\hline & Article name & Imaging modality & Neuroimaging findings \\
\hline 15 & $\begin{array}{l}\text { Coexistence of COVID-19 and acute ischemic } \\
\text { stroke report of four cases [22] }\end{array}$ & MRI_brain & $\begin{array}{l}\text { Total middle cerebral artery (MCA) infarction } \\
\text { Left lenticulostriate artery infarction } \\
\text { Right pontine infarction }\end{array}$ \\
\hline 16 & $\begin{array}{l}\text { Concomitant neurological symptoms observed } \\
\text { in a patient diagnosed with coronavirus disease }\end{array}$ & CT-head & No abnormality \\
\hline
\end{tabular}

in a patient diagnosed with coronavirus disease 2019 [23]

17 Coronavirus 2019 (COVID-19)-associated CT-head encephalopathies and cerebrovascular disease: MRI—brain the New Orleans experience [24]

18 COVID-19 presenting as stroke [25]

19 COVID-19 presenting with seizures [26]

20 COVID-19 related neuroimaging findings: a signal of thromboembolic complications and a strong prognostic marker of poor patient outcome [27]

21 COVID-19-associated encephalopathy with fulminant cerebral vasoconstriction: $C T$ and MRI findings [28]

22 COVID-19-associated encephalopathy: neurological manifestation of COVID-19 [29]

23 COVID-19-associated ophthalmoparesis and hypothalamic involvement [30]

24 COVID-19-associated pulmonary and cerebral thromboembolic disease [31]

25 COVID-19-related acute necrotizing

encephalopathy with brain stem involvement in MRL—brain a patient with aplastic anemia [32]
CT-head MRI-brain

MRI-brain

CT-head MRI-brain CT-head

CT-head
CTA
MRI-brain
CT-head
CT-head

CT_Head
MRI
MRA
MRV

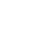

26 COVID-19-related strokes in adults below 55 years of age: a case series [33]

27 COVID-19-associated encephalitis mimicking glial tumor [34]

28 De novo status epilepticus in patients with COVID-19 [35]

$$
\begin{aligned}
& \text { CT-head } \\
& \text { MRI-brain } \\
& \text { CT_head } \\
& \text { MRI-brain }
\end{aligned}
$$

Focal encephalitides and vasculolitides

Diffuse hypoattenuation, focal hypodensities in deep structures, subacute ischemic strokes, and subcortical parenchymal hemorrhages

Viral encephalitis: restriction and FLAIR changes in corpus callosum as well as $B / L$ deep structures

Case 1-Loss of gray-white differentiation at the left occipital and parietal lobes, consistent with acute infarct.

Evolution of a large acute infarct in the left MCA territory with hyperdense appearance of left MCA vessels - consistent with an acute thrombus

Case 2-Moderate hypodensity in the right frontal lobe suggestive of an acute infarct

Case 3-Occlusion of the right internal carotid artery (ICA) at origin with a core infarct in the right MCA distribution and a surrounding ischemic penumbra

Case 4-acute infarct in the left medial temporal lobe

Chronic microvascular ischemic changes

Acute left MCA infarct

Multiple small acute infarcts in B/L cerebral hemispheres

Large acute hemorrhage in the brainstem and right cerebral hemisphere

Ischemic and hemorrhagic stroke, hypoxic anoxic brain injury, encephalitis

Severe cerebral edema with mass effect, diffuse cerebral sulcal effacement, brainstem compression with narrowing of the 4th ventricle due to downward cerebellar tonsillar herniation Severe diffuse cerebral arterial and dural venous sinus constriction

Hypodensity of bilateral thalami

Signal changes of brain parenchyma including insula, B/L dorsal frontal lobes, and thalamus with restricted diffusion of globus pallidus (features of encephalopathy)

T2/FLAIR Hyperintensity ( $\mathrm{HI})$ in the brainstem, including the medial temporal lobes, mammillary bodies, CN VI nuclei, thalami, and hypothalamus

Partial right Sylvian segment (M2), superior division occlusion and right opercular (M3), parietal segment occlusions Multiple, discrete, peripheral acute infarctions of the right MCA territory with some hemorrhagic conversion

Increased hypodensity and swelling of the brain stem, and a new area of cortical and subcortical hypodensity in the left occipital lobe suggestive of an acute posterior circulation infarct

Extensive, symmetrical changes in the supratentorial and infratentorial compartments.

Hemorrhage and diffuse swelling in the amygdalae and brain stem Microhemorrhage and extensive abnormal signal were found in a symmetrical distribution within the dorsolateral putamina, ventrolateral thalamic nuclei, sub-insular regions, splenium of the corpus callosum, cingulate gyri, and subcortical perirolandic regions

Right MCA, Left MCA, and left basal ganglia infarction

Hyperintense signal in the left temporal lobe in T2 and T2 FLAIR imaging suggestive of high-grade glioma

No abnormality 
Table 1 Reported studies on COVID-19 patients with neurological manifestations with positive findings on major imaging modalities (Continued)

\begin{tabular}{|c|c|c|c|}
\hline & Article name & Imaging modality & Neuroimaging findings \\
\hline 29 & $\begin{array}{l}\text { Delirium as a presenting feature in COVID-19: } \\
\text { neuroinvasive infection or autoimmune enceph- } \\
\text { alopathy? [36] }\end{array}$ & $\begin{array}{l}\text { CT_-head } \\
\text { MRI_brain }\end{array}$ & $\begin{array}{l}\text { Case } 1-3 \text { hyperintense foci on diffusion suggesting cellular } \\
\text { infiltration/inflammation or small infarcts } \\
\text { Case } 2 \text {-Changes in the limbic system with partial diffusion } \\
\text { restriction, consistent with limbic encephalitis }\end{array}$ \\
\hline 30 & $\begin{array}{l}\text { Emergency room neurology in times of COVID- } \\
\text { 19: malignant ischaemic stroke and SARS-CoV-2 } \\
\text { infection [7] }\end{array}$ & $\begin{array}{l}\text { CT-head } \\
\text { CTA }\end{array}$ & $\begin{array}{l}\text { Established infarct in the territory of the left MCA with a mild } \\
\text { deviation of the midline } \\
\text { Occlusion of the left MCA, ACA and ICA with a free-floating } \\
\text { thrombus in the ascending aorta }\end{array}$ \\
\hline 31 & $\begin{array}{l}\text { Encephalopathy and seizure activity in a COVID- } \\
19 \text { well controlled HIV patient [37] }\end{array}$ & $\begin{array}{l}\text { CT-head } \\
\text { MRl_brain }\end{array}$ & No abnormality \\
\hline 32 & $\begin{array}{l}\text { COVID-19-associated myositis with severe } \\
\text { proximal and bulbar weakness [38] }\end{array}$ & MRI-brain & $\begin{array}{l}\text { Extensive edema and enhancement suggestive of inflammatory } \\
\text { myopathy } \\
\text { Central nonenhancement in the vastus medialis, consistent with } \\
\text { myonecrosis }\end{array}$ \\
\hline 33 & $\begin{array}{l}\text { Evolution and resolution of brain involvement } \\
\text { associated with SARS- CoV2 infection: a close }\end{array}$ & $\begin{array}{l}\text { CT_head } \\
\text { MRI-brain }\end{array}$ & $\begin{array}{l}\text { High signal abnormalities in B/L pons, thalami, and medial temporal } \\
\text { lobes }\end{array}$ \\
\hline
\end{tabular}
clinical_-paraclinical follow up study of a case [39]

34 First case of focal epilepsy associated with SARS-coronavirus-2 [40]

$$
\begin{aligned}
& \text { CTA } \\
& \text { MRI-brain } \\
& \text { MRI-brain }
\end{aligned}
$$

35 First case of SARS-COV-2 sequencing in cerebrospinal fluid of a patient with suspected demyelinating disease [41]

36 First motor seizure as presenting symptom of SARS-CoV-2 infection [42]

37 Focal EEG changes indicating critical illness associated cerebral microbleeds in a COVID-19 patient [43]

38 Fulminant cerebral edema as a lethal manifestation of COVID-19 [44]

39 Intracranial hemorrhage in a young COVID-19 patient [45]

40 Ischemic stroke associated with novel coronavirus 2019: a report of three cases [46]

41 Locked-in with COVID-19 [47]

42 Macrothrombosis and stroke in patients with mild COVID-19 infection [48]

43 Malignant cerebral ischemia in a COVID-19 infected patient: case review and histopathological findings [49] tion [50] patients presenting with acute neurological deficits [51] MRA

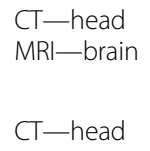

MRI-brain toward the brain stem with obliteration of basal cerebral cisterns, multiple juxtacortical microbleeds, which may be compatible with venous hemorrhagic infarction, effacement of ventricles and peripheral sulci and gyri

Large, multiloculated right ICH associated with vasogenic edema; uncal and sub-falcine herniation without an underlying ischemic stroke

Case 1. Low-density lesion at right cerebellar suggestive of acute ischemic stroke

Case 2. Attenuation and effacement at the right hemisphere around the Sylvian fissure

Case 3. Hypo-density at left basal ganglion

Numerous foci of restricted diffusion within the pons, (correlating with FLAIR signal abnormality) consistent with acute pontine ischemic infarcts

Decreased flow in distal right vertebral artery with a patent basilar artery

Nonocclusive thrombus in the right common carotid artery, extending into the ICA

Acute stroke in the territory of the right MCA

Large right MCA infarct

Supratentorial periventricular demyelinating lesions in right occipital lobe and left temporal

Case 1 -B/L subacute infarcts, basilar cistern effacement, a left-toright midline shift, intraparenchymal hemorrhage, sub-falcine, and uncal herniation 
Table 1 Reported studies on COVID-19 patients with neurological manifestations with positive findings on major imaging modalities (Continued)

\begin{tabular}{|c|c|c|c|}
\hline & Article name & Imaging modality & Neuroimaging findings \\
\hline & & & $\begin{array}{l}\text { Case 2-Pre-op - large volume hemorrhage within the right } \\
\text { temporal and parietal lobes, surrounding edema, midline shift, uncal } \\
\text { herniation, and entrapment of the temporal horns. } \\
\text { Post-op—right-sided craniectomy and anterior temporal } \\
\text { lobectomy_improvement in overall mass effect }\end{array}$ \\
\hline 46 & $\begin{array}{l}\text { Neuralgic amyotrophy following infection with } \\
\text { SARS-CoV-2 [52] }\end{array}$ & MRI_brain & $\begin{array}{l}\text { Edema and inflammatory contrast enhancement of the right distal } \\
\text { median nerve } \\
\text { Minor right C5-C6 disk protrusion without nerve root impingement, } \\
\text { and mild T2-signal increase of the ipsilateral C7-C8 roots, suggestive } \\
\text { of proximal edema }\end{array}$ \\
\hline 47 & $\begin{array}{l}\text { Neurological manifestations in critically ill } \\
\text { patients with COVID-19: a retrospective study } \\
\text { [53] }\end{array}$ & CT-head & $\begin{array}{l}\text { Low density lesions in the following: } \\
\text { Case 1. B/L parietal and frontal lobes, right occipital lobe } \\
\text { Case 2. Left hemisphere, } B / L \text { temporal, and occipital lobes } \\
\text { Case 3. B/L parietal and frontal lobes } \\
\text { Case 4. Right hemisphere } \\
\text { Case 5. Left midbrain } \\
\text { Case 6. Right side of the periventricular area }\end{array}$ \\
\hline 48 & $\begin{array}{l}\text { Novel coronavirus (COVID-19)-associated } \\
\text { Guillain-BarrÃ@ syndrome: case report [54] }\end{array}$ & MRI—spine & No evidence of myelopathy or radiculopathy \\
\hline 49 & $\begin{array}{l}\text { Olfactory gyrus intracerebral hemorrhage in a } \\
\text { patient with COVID-19 infection [55] }\end{array}$ & $\begin{array}{l}\text { CT-head } \\
\text { MRI—brain }\end{array}$ & $\begin{array}{l}\text { Right olfactory gyrus ICH with surrounding edema, with no } \\
\text { evidence of soft tissue injury or cerebral contusion }\end{array}$ \\
\hline 50 & $\begin{array}{l}\text { Orbitofrontal involvement in a neuroCOVID-19 } \\
\text { patient [56] }\end{array}$ & MRI—brain & $\begin{array}{l}\text { Hyperintensity of the right orbital prefrontal cortex adjacent to the } \\
\text { olfactory bulb, which seemed to spread toward the right caudate } \\
\text { nucleus and mesial prefrontal cortex }\end{array}$ \\
\hline 51 & $\begin{array}{l}\text { Posterior reversible encephalopathy syndrome } \\
\text { (PRES): another imaging manifestation of } \\
\text { COVID-19 [57] }\end{array}$ & $\begin{array}{l}\text { CT_head } \\
\text { MRI_brain }\end{array}$ & $\begin{array}{l}\text { Symmetric hypoattenuation of the external capsules and posterior } \\
\text { subcortical cerebral white matter } \\
\text { Hyperintensity with increased diffusion in the internal and external } \\
\text { capsules, subcortical, deep cerebral, and cerebellar white matter }\end{array}$ \\
\hline 52 & $\begin{array}{l}\text { Prolonged confusional state as first } \\
\text { manifestation of COVID-19 [6] }\end{array}$ & CT-head & Mild chronic small vessel ischemic changes \\
\hline 53 & $\begin{array}{l}\text { Reversible cerebral vasoconstriction syndrome } \\
\text { and dissection in the setting of COVID-19 infec- } \\
\text { tion [58] }\end{array}$ & CT-head & $\begin{array}{l}\mathrm{B} / \mathrm{L} \text { convexity } \mathrm{SAH} \\
\text { Left vertebral artery dissection }\end{array}$ \\
\hline 54 & $\begin{array}{l}\text { Reversible encephalopathy syndrome (PRES) in } \\
\text { a COVID-19 patient [59] }\end{array}$ & $\begin{array}{l}\text { CT_-head } \\
\text { CTA } \\
\text { MRI-brain }\end{array}$ & $\begin{array}{l}\text { Posterior frontal and temporo-parieto-occipital symmetrical B/L } \\
\text { hypodensity of the subcortical white matter, and a small left occipi- } \\
\text { tal parenchymal hemorrhage } \\
\text { Absence of vascular malformation and alterations of posterior circle } \\
\text { vessel caliber- suggestive of vasoconstriction mechanism } \\
\text { Onset of right temporal hypodensity, correlated to hemorrhagic } \\
\text { process }\end{array}$ \\
\hline 55 & $\begin{array}{l}\text { SARS-CoV-2-associated Guillain-Barrẽ® syn- } \\
\text { drome with dysautonomia [60] }\end{array}$ & CT-head & No abnormalities \\
\hline 56 & $\begin{array}{l}\text { Severe headache as the sole presenting } \\
\text { symptom of COVID-19 pneumonia: a case re- } \\
\text { port [61] }\end{array}$ & $\begin{array}{l}\text { MRI-brain } \\
\text { MRA }\end{array}$ & $\begin{array}{l}\text { Nonspecific white matter hyperintensities } \\
\text { Normal MRA }\end{array}$ \\
\hline 57 & $\begin{array}{l}\text { Steroid-responsive encephalitis in coronavirus } \\
\text { disease } 2019 \text { [62] }\end{array}$ & $\begin{array}{l}\text { CT-head } \\
\text { MRI—brain }\end{array}$ & No abnormalities \\
\hline 58 & $\begin{array}{l}\text { Stroke and COVID19: not only a large-vessel dis- } \\
\text { ease [63] }\end{array}$ & $\begin{array}{l}\text { CTA } \\
\text { MRI-brain }\end{array}$ & $\begin{array}{l}\text { Small cortical acute ischemic lesions in the right pre- and post- } \\
\text { central gyrus, without signs of previous ischemic lesions and } \\
\text { hemorrhagic infarction }\end{array}$ \\
\hline 59 & $\begin{array}{l}\text { Stroke in patients with SARS-CoV-2 infection: } \\
\text { case series [64] }\end{array}$ & $\begin{array}{l}\text { CT_head } \\
\text { MRI_brain }\end{array}$ & $\begin{array}{l}\text { Case } 1-C T \text { showed numerous hypodense lesions involving } \\
\text { different cortical and subcortical regions of } B / L \text { cerebral hemispheres } \\
\text { Case } 2 \text {-Ischemic lesion involving the frontal lobe on the right side; } \\
\text { Occlusion of the right pericallosal artery; multiple, B/L supratentorial } \\
\text { and infra-tentorial ischemic lesions. } \\
\text { Case } 3 \text { - Small hypodense area in the right thalamus of presumed } \\
\text { ischemic origin } \\
\text { Case } 4 \text {-Focal T2-FLAIR HI lesion in the left precentral gyrus with a } \\
\text { bright signal on DWI sequence, and mild post-contrast }\end{array}$ \\
\hline
\end{tabular}


Table 1 Reported studies on COVID-19 patients with neurological manifestations with positive findings on major imaging modalities (Continued)

\begin{tabular}{|c|c|c|c|}
\hline & Article name & Imaging modality & Neuroimaging findings \\
\hline & & & $\begin{array}{l}\text { enhancement of the head of right caudate nucleus } \\
\text { Case } 5 \text { - Large cerebellar hemorrhage compressing the brainstem } \\
\text { and } 4 \text { th ventricle causing a subsequent obstructive hydrocephalus } \\
\text { Case } 6 \text {-Diffuse cerebral edema with loss of normal gray-white } \\
\text { matter differentiation and obliteration of CSF spaces; large right } \\
\text { frontal hemorrhage with other smaller hemorrhages and a bright } \\
\text { spot within the sagittal sinus suspected for dural sinus thrombosis }\end{array}$ \\
\hline 60 & $\begin{array}{l}\text { Subcortical myoclonus in COVID-19: compre- } \\
\text { hensive evaluation of a patient [65] }\end{array}$ & MRI-brain & Cerebral small-vessel disease of moderate severity \\
\hline 61 & $\begin{array}{l}\text { Thalamic perforating artery stroke on computed } \\
\text { tomography perfusion in a patient with } \\
\text { coronavirus disease } 2019 \text { [66] }\end{array}$ & $\begin{array}{l}\text { CT-head } \\
\text { MRI-brain }\end{array}$ & $\begin{array}{l}\text { Small focal hypoperfusion in the paramedian perforating vascular } \\
\text { territory supplying the left medial thalamus } \\
2 \text { punctate acute ischemic lesions in each cerebellar hemisphere }\end{array}$ \\
\hline 62 & $\begin{array}{l}\text { Two patients with acute meningoencephalitis } \\
\text { concomitant with SARS-CoV-2 infection [67] }\end{array}$ & MRI—brain & Normal \\
\hline 63 & $\begin{array}{l}\text { COVID-19 is associated with an unusual pattern } \\
\text { of brain microbleeds in critically ill patients [68] }\end{array}$ & MRI—brain & $\begin{array}{l}\text { Microbleeds in unusual distribution, particularly involving the } \\
\text { anterior/posterior limbs of internal capsule (five patients), middle } \\
\text { cerebellar peduncles ( } 5 / 9 \text { patients), and the corpus callosum }\end{array}$ \\
\hline
\end{tabular}

centered around respiratory pathogenesis and manifestations of the virus. However, recent focus has shifted toward its invasive nature and complications in the nervous system. There has been a surge in the number of cases documenting the nervous system involvement in COVID-19 positive patients with minimal respiratory involvement. Some studies reported absence of SARS-CoV-2 RNA in the nasal and throat swabs even though it was found to be present in the cerebrospinal fluid upon further investigations [10]. However, our understanding of the pathophysiology behind such neurological manifestations and the data on neuroimaging still remains limited.

\section{Pathogenesis}

Currently, there are 4 mechanisms of neuro-invasion that have been hypothesized.

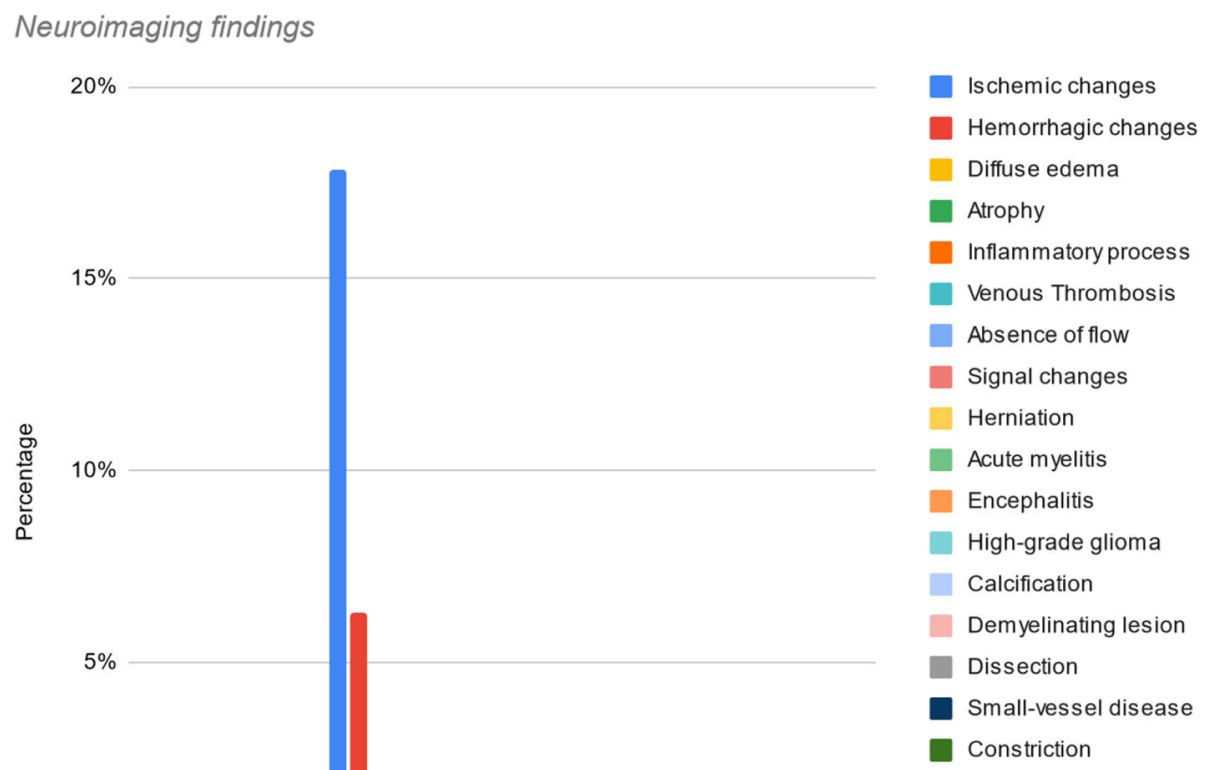

Fig. 2 Evaluation of positive neurological findings on CT scan and MRI of COVID-19 infected patients. To demonstrate positive neuroimaging findings, patients with normal findings on imaging or findings unrelated to COVID-19 were not included 


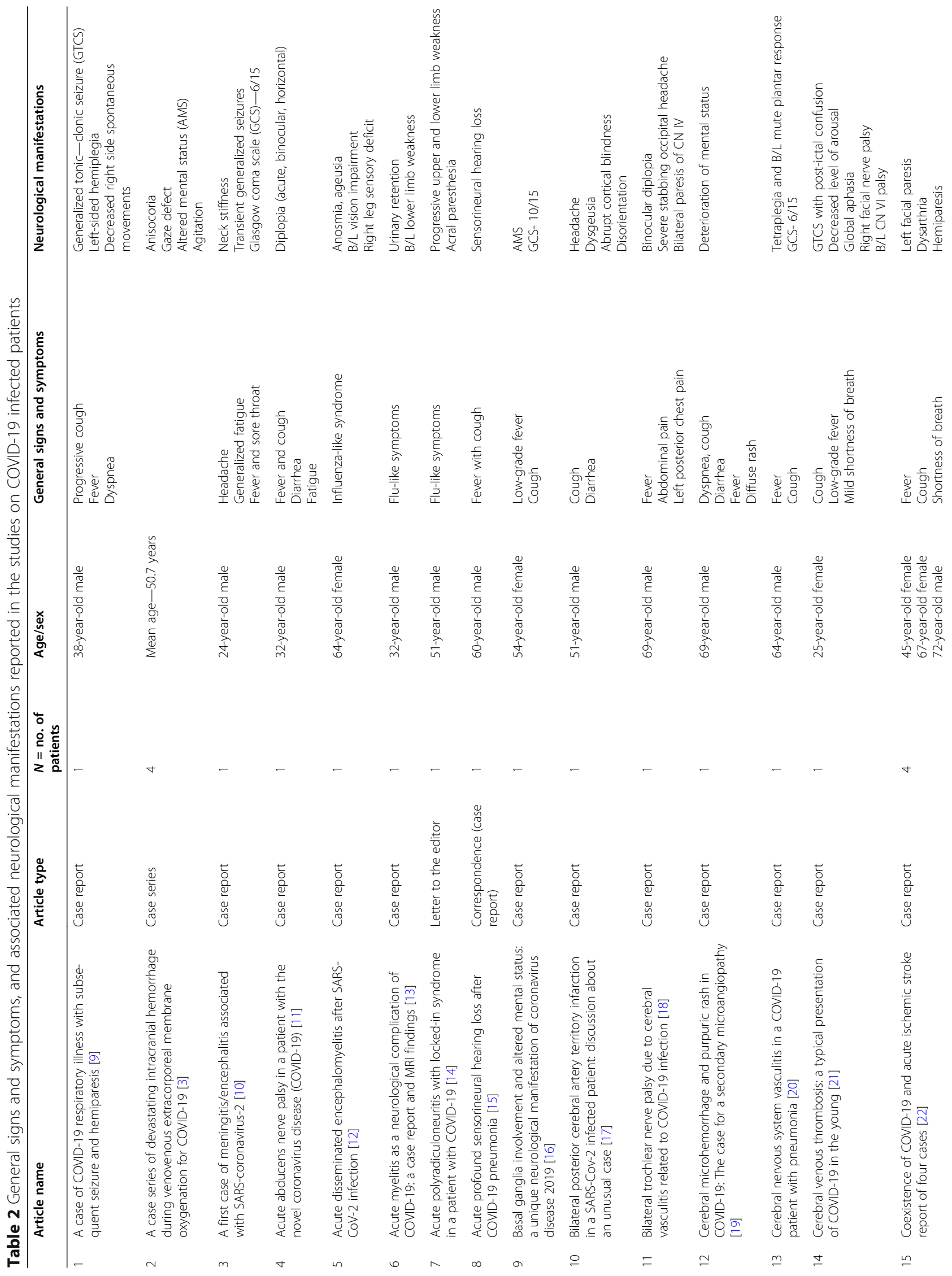




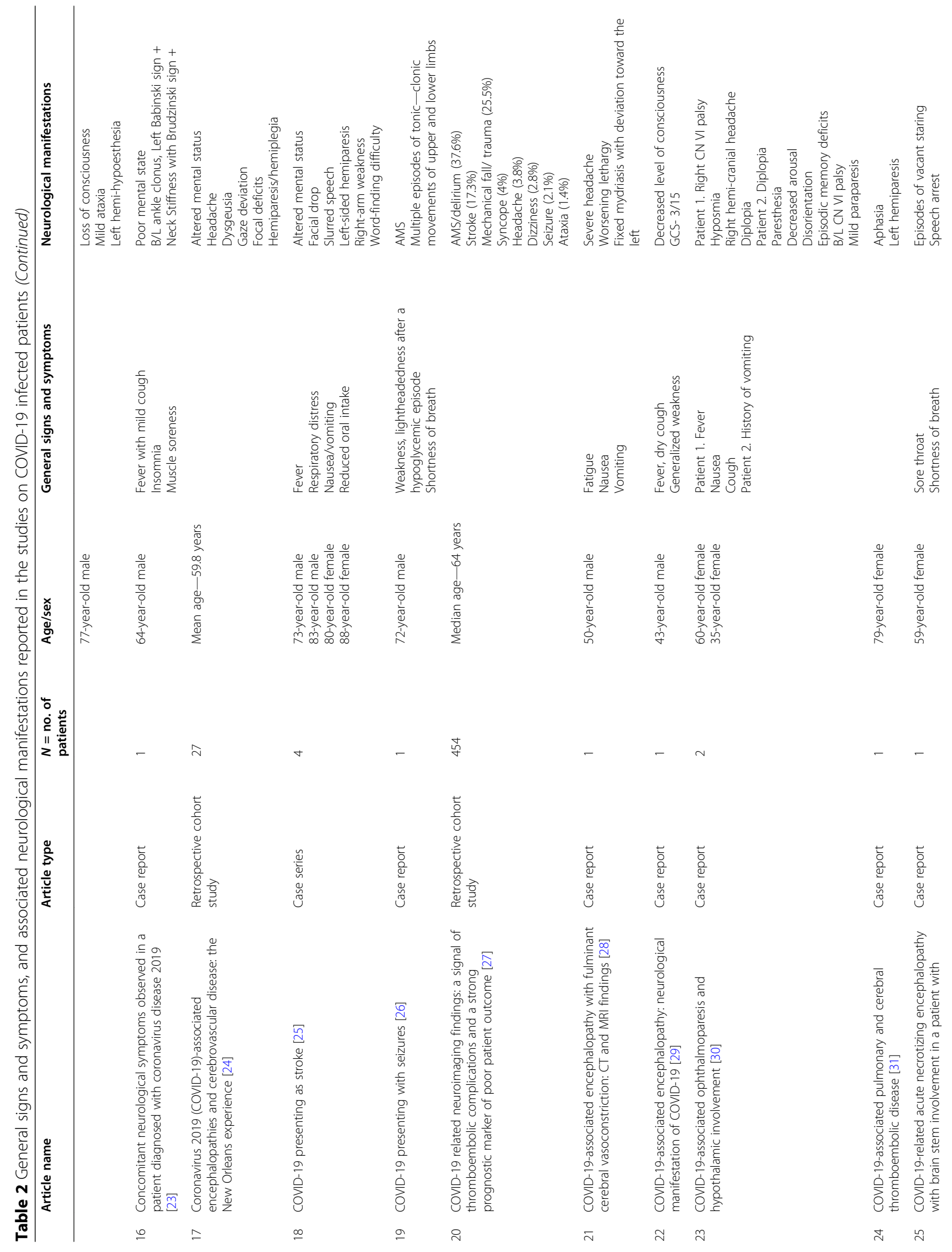




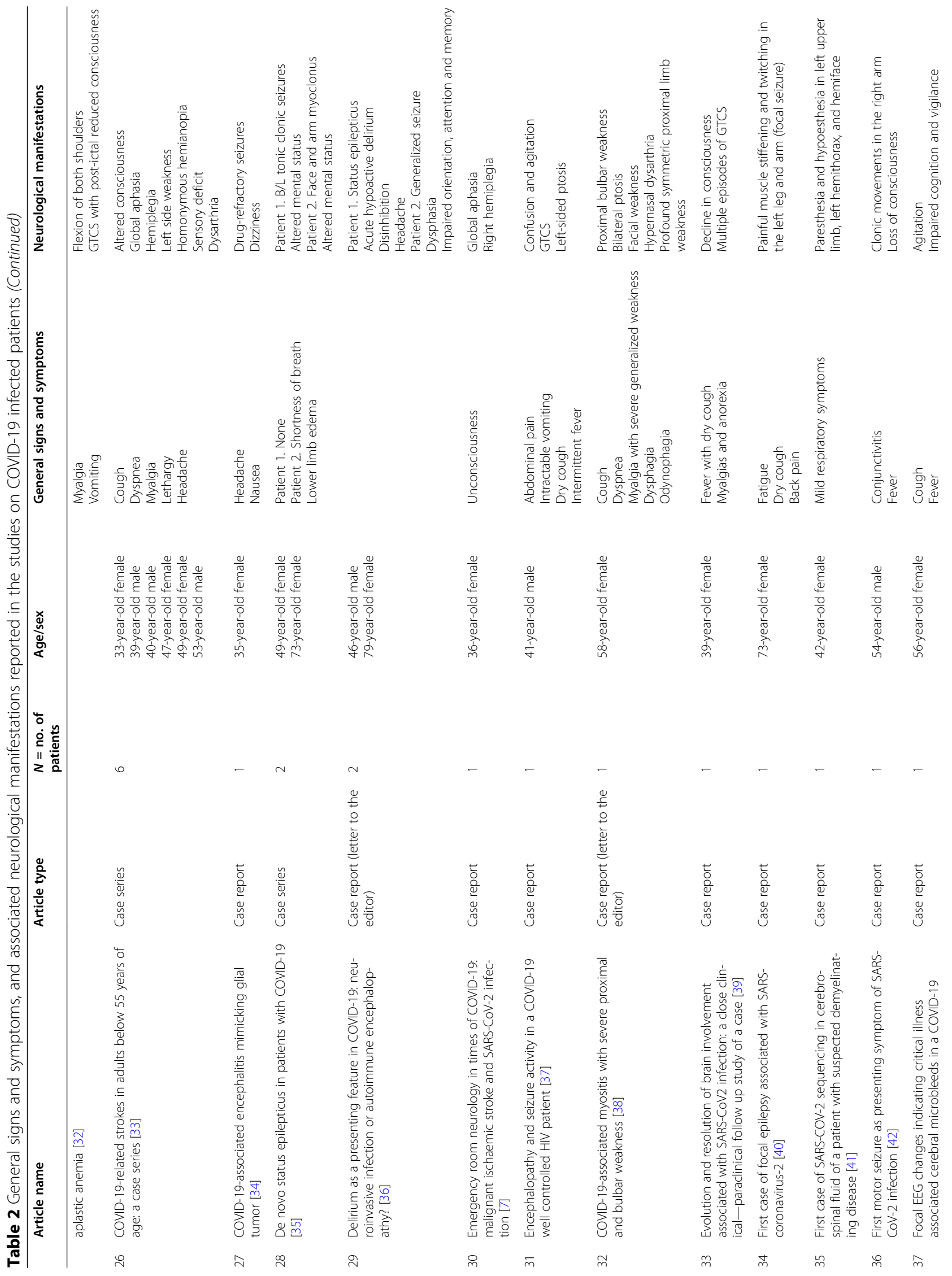




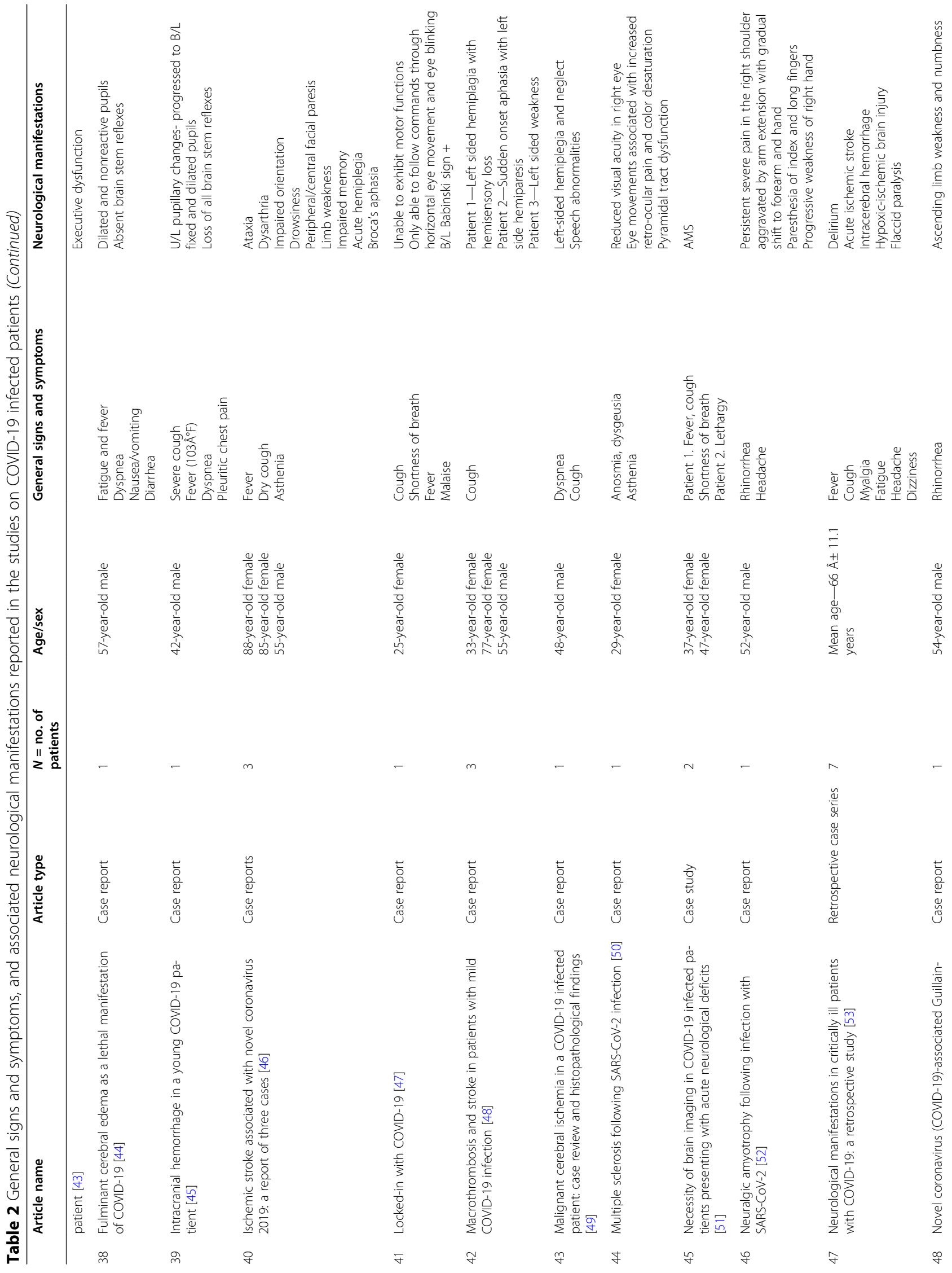




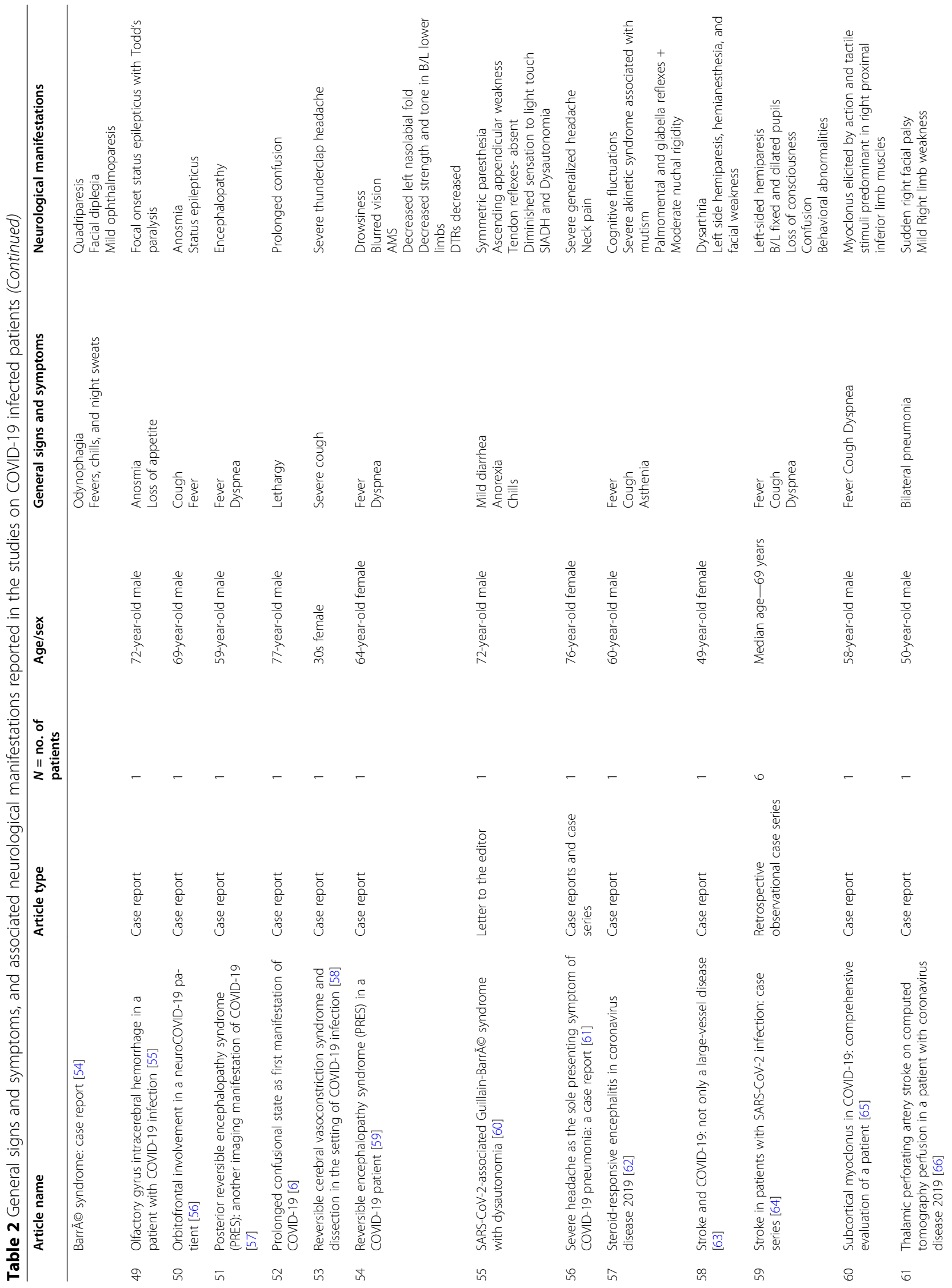




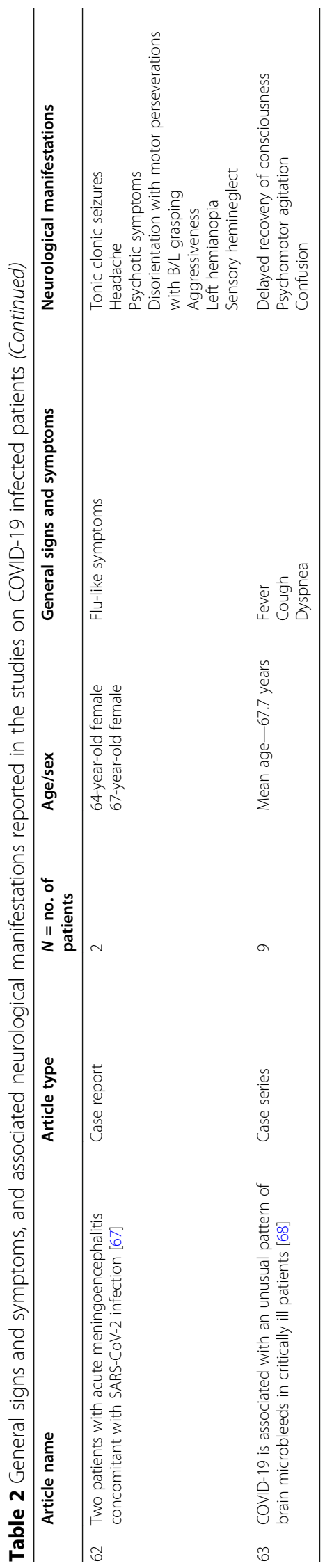




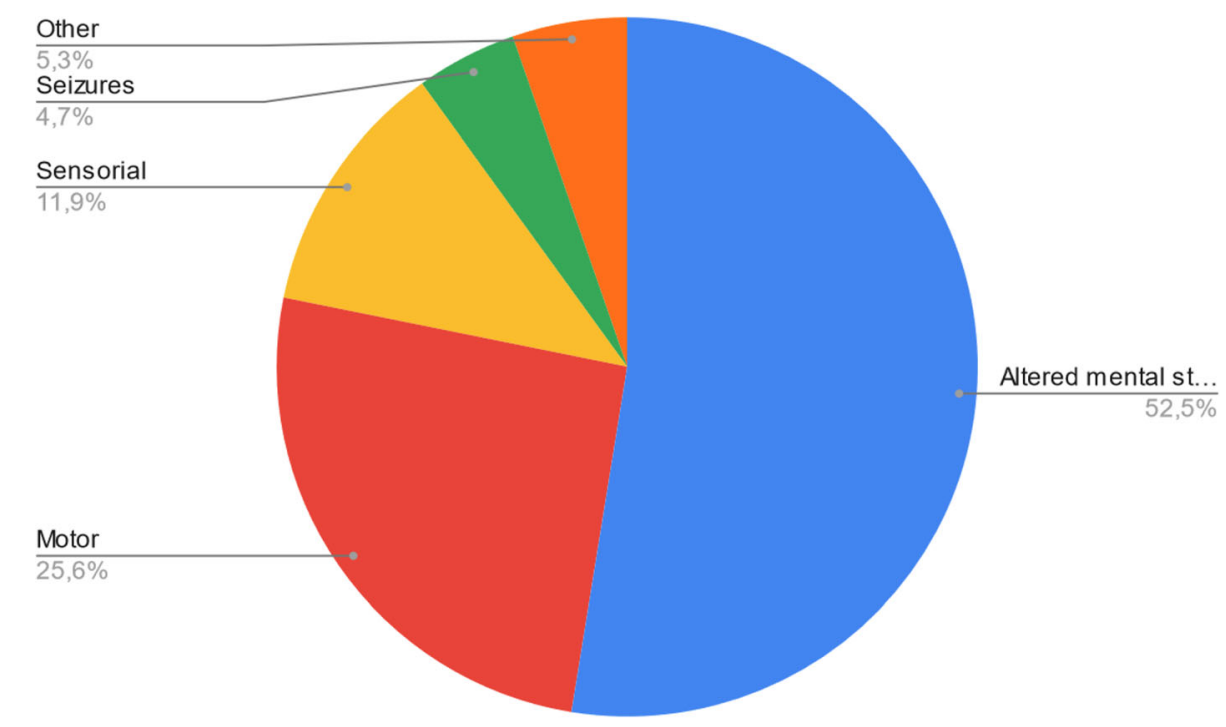

Fig. 3 Neurological manifestations in patients infected with SARS-CoV2

\section{Receptor modulation}

The body has a traditional angiotensin-converting enzyme (ACE) in lung capillaries which is a part of the renin-angiotensin-aldosterone system (RAAS) and is involved in regulating blood pressure. COVID-19 is known to use ACE2 receptors, present in the endothelium of the heart, kidneys, and alveolar cells, especially alveolar type 2 (AT2), for cell entry. Binding to these receptors, the virus hampers the body's natural mechanism of decreasing blood pressure thus increasing the likelihood of intracranial hemorrhages and stroke [69-71]. The neurons and glial cells are known to have ACE2 receptors, possibly explaining the neurotropism of the virus [72]. The mechanism of entry hypothesized is that the spikes present on the virus might link with ACE2 on the capillary endothelium, damaging the blood-brain barrier (BBB) and thus gaining entry into CNS [71]. The two areas are involved in the central regulation of respiration-nucleus of the tractus solitarius and ventrolateral medulla also express ACE2 receptors.

\section{Trans-cribrial transmission}

The anosmia in many cases points toward viral entry via olfactory bulb and across the cribriform plate [71]. This mechanism has been linked with murine experiments which led to the detection of the virus in the midbrain, basal ganglia, infralimbic cortex, and the piriform via intranasal inoculation of

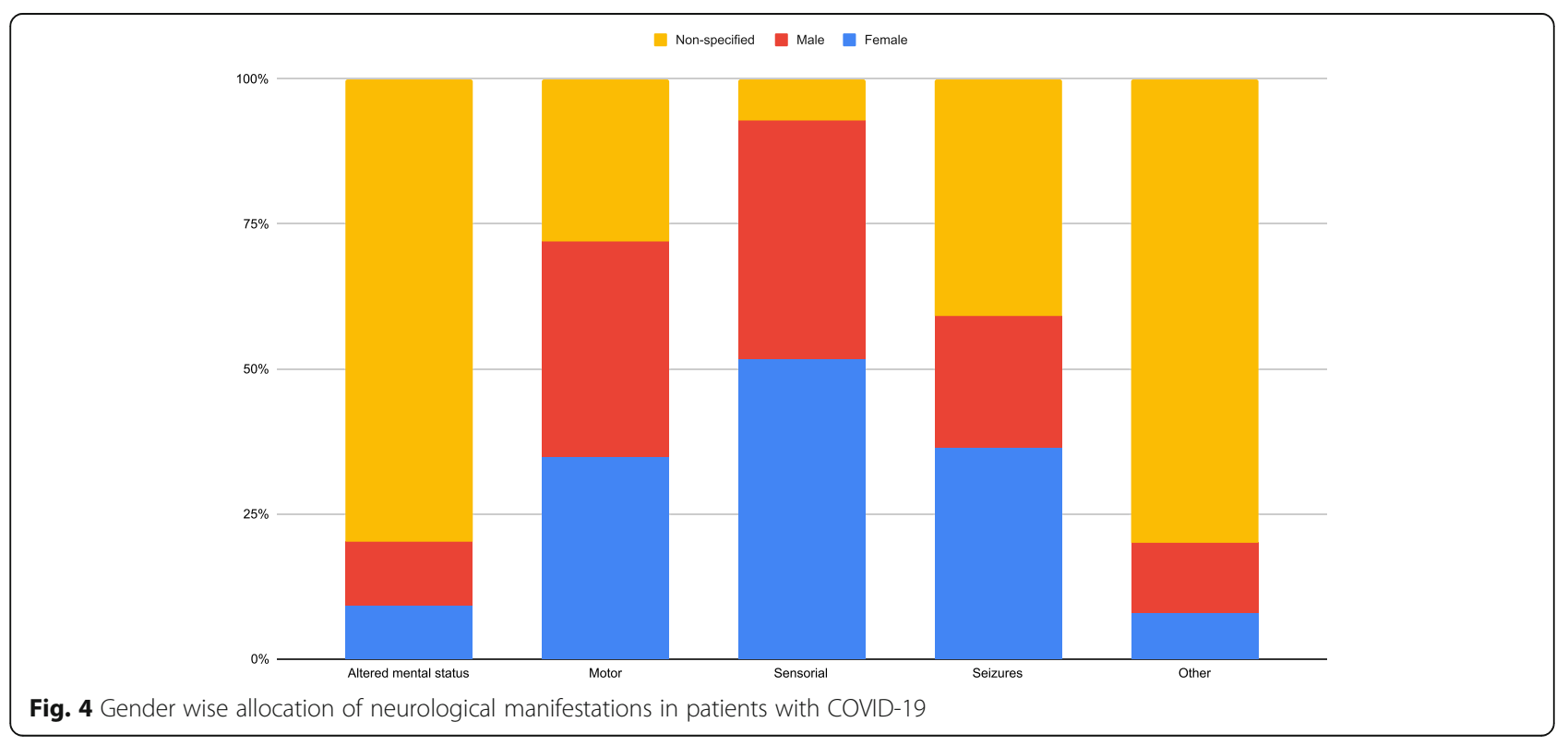


COVID-19 [69, 73]. SARS-CoV-2 may use ACE2 or trans-membrane protease serine 2 (TMPRSS2) receptors to infect olfactory receptor neurons in the olfactory epithelium [74].

\section{Blood-brain barrier spread}

Prior research of SARS-CoV and MERS has shown that cytokines like tumor necrosis factor (TNF- $\alpha$ ) and interleukins (IL-6 and IL-1) led to direct death of neurons in the respiratory center in the medulla $[73,75]$. The prolific response of the immune system leads to an enormous release of these cytokines and chemokines. They lead to increased permeability and breakdown of the BBB resulting in increased entry of leukocytes. They can also precipitate glutamate receptor-induced neuronal hyperexcitability which may be the reason behind acute seizures linked with the virus. Furthermore, hyperinflammatory and immune responses can result in cytokine storm syndrome which is a severe manifestation of COVID-19 [72].

\section{Trans-synaptic transmission}

The entry of the virus into CNS through the peripheral nerves is another hypothesized secondary pathway. The alveoli in the lungs have sensory innervations that detect changes in $\mathrm{O}_{2}$ and $\mathrm{CO}_{2}$. These pathways run-up to the respiratory centers in the brainstem and send signals to the pre-synapses there. Porcine hepatitis E virus studies depict a similar pathway of transmission and since HEV is almost homologous to $\mathrm{hCoV}-\mathrm{OC} 43^{2}$, a close relative of SARS-CoV-2, it might be the same case here [76].

The neuropathological mechanisms reported to play a role in the development of neurological disorders in COVID-19 are-hypoxic brain injury and immunemediated damage. The hypoxic brain injury is believed to be due to the alveolar gas exchange disorders caused by proliferation of virus in the alveolar cells [71]. As mentioned above, severe immune response resulting in a cytokine storm can also lead to the development of neurological manifestations [72].

\section{Neuro-radiological manifestations}

About $17.85 \%$ patients who underwent neuroimaging were found to be having ischemic changes suggestive of a stroke. Rajan Jain [27] and colleagues found that the inpatient COVID-19 positive population with stroke had a poor outcome. Similarly, in a systematic review by Sebastian Fredman [77] and colleagues, mortality rate of $45 \%$ was reported in the admitted COVID-19 positive patients affected with ischemic stroke. Large vessel involvement was found to be the most common, particularly the MCA. The association of COVID-19 and cerebrovascular disease has been well established but it is still unclear whether this is a de novo occurrence or a complication of already existing atheromatous plaques [78]. The role of stenotic lesions resulting in ischemic changes is also unclear. Hemorrhagic changes were found to be the second most common positive imaging finding particularly involving the corpus callosum and subcortical parenchyma. Aikaterini Fitsiori [68] and colleagues reported that COVID-19 or its treatment may cause unusual microbleeds, predominantly affecting the corpus callosum. All these patients were suffering from severe or moderate acute respiratory distress. This could be due to microangiopathic changes resulting from the cytokine-induced pathogenesis discussed above. Simon Pao [79] and colleagues concluded that ischemic changes were seen in both mild and severe infections whereas hemorrhagic changes were more prevalent in severely affected patients.

\section{Neurological findings}

In this study, we observe that COVID-19 patients presented with a variety of neurological complications. In our review, the most prevalent finding has been altered mental status (52.5\%). Among the earliest articles about COVID-19 by Mao [5] and colleagues was a retrospective study that showed that $36.4 \%$ of patients presented with nervous system abnormalities, and among them, patients who had severe disease were more vulnerable to acute cerebrovascular disease and altered consciousness. The neurotropism of the virus leading to inflammation in the CNS may be a cause of altered mental status. Macrophages and microglia which proliferate to the areas concentrated by viral antigen have shown to cause demyelination leading to memory and cognitive deficits. This was observed in a murine study conducted with several strains of the virus [80, 81]. Nepal G [80]. and colleagues mention the importance of early identification of altered mental status in SARS-CoV-2 patients to check for a possible reversible cause leading to its early management. Confusion, agitation, drowsiness, lethargy, and psychotic symptoms were some of the most commonly observed subsets of symptoms included in altered mental status (Table 2).

Stroke has been observed to be the most frequent finding in neuroimaging of patients affected by COVID19. A peculiar thing about COVID-19 related strokes is that they can be found in younger patients as observed in a case series by Ashrafi [33] which explores this association in patients younger than the age of 55 , where the youngest patient, a 33-year-old, was without any previous comorbidities. Several studies have mentioned the prothrombotic and inflammatory nature of COVID-19, and some reports mention stroke symptoms being the first presentation in many cases. Lee SG [82] and Spence JD [83] mention that about $20-55 \%$ of SARS-CoV-2 patients exhibited laboratory values indicating 
coagulopathies. The prevalence of ischemic strokes is slightly higher than that of hemorrhagic strokes as seen in a 6-patient case series by Morassi [64] where 4 were affected by ischemic stroke and 2 by hemorrhagic. Other frequently seen manifestations include paralysis, headaches, and altered speech.

As far as we know, this is the only study with documentation of reports published until August 2020 which is based on the nervous system involvement and neuroradiological findings of COVID-19 patients. The limitations of our study were that a subset of reported neurological or neuroimaging findings in severely ill and elderly patients may be incidental. The radiological findings might have been susceptible to clinical bias hence it is difficult to standardize them. Radiological imaging presumably is performed selectively on those presenting with notable neurological involvement, leaving out the probable findings in those diseases which are milder in nature, as routine imaging may increase the risk of transmission of the virus. Our study only included articles published in the English language.

\section{Conclusion}

In the past few months of the global pandemic, the connection between COVID-19 and neurological manifestations has been growing substantially. Having strong knowledge about such associations will prove to be instrumental in early detection, isolation, and care of patients who present with unusual neurologic symptoms, especially during the ongoing pandemic. Focus on longterm neurologic sequelae and neuroimaging findings is necessary to further the research on the neurotropic involvement of SARS-CoV-2.

\section{Abbreviations}

ACE: Angiotensin-converting enzyme; ACE2: Angiotensin-converting enzyme 2; AT2: Alveolar type 2 cells; BBB: Blood-brain barrier; CNS: Central nervous system; CT: Computed tomography; HEV: Hepatitis E virus; ICA: Internal carotid artery; IL-1: Interleukin 1; IL-6: Interleukin 6; MCA: Middle cerebral artery; MRA: Magnetic resonance angiography; MRI: Magnetic resonance imaging; RAAS: Renin angiotensin aldosterone system; SARS-CoV2: Severe acute respiratory syndrome-coronavirus 2; TMPRSS2: Transmembrane protease serine 2; TNF: Tumor necrosis factor

\section{Acknowledgements}

Not applicable

\section{Authors' contributions}

NM contributed to the conception, design, acquisition, analysis of data, drafted the work and approved the submitted version, and has agreed to be personally accountable for their contributions. MAF contributed to the conception, design, acquisition, analysis of data, drafted the work and approved the submitted version, and has agreed to be personally accountable for their contributions. CR contributed to the conception, design, acquisition, analysis of data, drafted the work and approved the submitted version, and has agreed to be personally accountable for their contributions. NK contributed to the conception, design, acquisition, analysis of data, drafted the work and approved the submitted version, and has agreed to be personally accountable for their contributions. SV contributed to the conception, design, acquisition, analysis of data, drafted the work and approved the submitted version, and has agreed to be personally accountable for their contributions. ES contributed to the conception, design, acquisition, analysis of data, drafted the work and approved the submitted version, and has agreed to be personally accountable for their contributions. JJ contributed to the conception, design, acquisition, analysis of data, drafted the work and approved the submitted version, and has agreed to be personally accountable for their contributions. AA contributed to the conception, design, acquisition, analysis of data, drafted the work and approved the submitted version, and has agreed to be personally accountable for their contributions. The authors read and approved the final manuscript.

\section{Funding}

The authors declare that no funding was received for this research.

\section{Availability of data and materials}

The authors declare that the data supporting the findings of this study are available within the article [and its supplementary information files].

\section{Declarations}

Ethics approval and consent to participate

Not applicable

\section{Consent for publication}

Not applicable

\section{Competing interests}

The authors declare that they have no competing interests.

\section{Author details}

${ }^{1}$ Jawaharlal Nehru Medical College, Belagavi, Karnataka, India. ${ }^{2}$ Quaid e Azam Medical College, Bahawalpur, Pakistan. ${ }^{3}$ Tecnologico de Monterrey, Escuela de Medicina y Ciencias de la Salud, Monterrey Nuevo Leon, Mexico. ${ }^{4}$ Indira Gandhi Government Medical College \& Mayo Hospital, Nagpur, Maharashtra, India. ${ }^{5}$ Kazan State Medical University, Kazan, Russia. ${ }^{6}$ M.S Ramaiah Medical College, Bangalore, Karnataka, India. ${ }^{7}$ Liaquat University of Medical and Health Sciences, Jamshoro, Pakistan.

Received: 11 January 2021 Accepted: 17 May 2021

Published online: 02 June 2021

\section{References}

1. Zhu N, Zhang D, Wang W, Li X, Yang B, Song J, et al. A novel coronavirus from patients with pneumonia in China, 2019. N Engl J Med. 2020;382(8): 727-33. https://doi.org/10.1056/NEJMoa2001017.

2. WHO Coronavirus Disease (COVID-19) Dashboard. 2020 [cited 2020 2020-0831]; Available from: https://covid19.who.int/.

3. Usman AA, Han J, Acker A, Olia SE, Bermudez C, Cucchiara B, et al. A case series of devastating intracranial hemorrhage during venovenous extracorporeal membrane oxygenation for COVID-19. J Cardiothorac Vasc Anesth. 2020;34(11):3006-12. https://doi.org/10.1053/j.jvca.2020.07.063.

4. Niazkar HR, Zibaee B, Nasimi A, Bahri N. The neurological manifestations of COVID-19: a review article. Neurol Sci. 2020;41(7):1667-71. https://doi.org/1 0.1007/s10072-020-04486-3.

5. Mao L, Jin H, Wang M, Hu Y, Chen S, He Q, et al. Neurologic manifestations of hospitalized patients with coronavirus disease 2019 in Wuhan. China. JAMA Neurol. 2020;77(6):683-90. https://doi.org/10.1001/jamaneurol.202 0.1127.

6. Butt I, Sawlani V, Geberhiwot T. Prolonged confusional state as first manifestation of COVID-19. Annals of Clinical and Translational Neurology. 2020;7(8):1450-2. https://doi.org/10.1002/acn3.51067.

7. Gonzalez-Pinto T, Luna-Rodriguez A, Moreno-Estebanez A, Agirre-Beitia G, Rodriguez-Antiguedad A, Ruiz-Lopez M. Emergency room neurology in times of COVID-19: malignant ischaemic stroke and SARS-CoV-2 infection. Eur J Neurol. 2020;27(9):e35-6. https://doi.org/10.1111/ene.14286.

8. Tsivgoulis G, Palaiodimou L, Katsanos AH, Caso V, Kohrmann M, Molina C, et al. Neurological manifestations and implications of COVID-19 pandemic. Ther Adv Neurol Disord. 2020;13:1756286420932036.

9. Hamidi A, Sabayan B, Sorond F, Nemeth AJ, Borhani-haghighi A. A case of Covid-19 respiratory illness with subsequent seizure and hemiparesis. Galen Medical Journal. 2020;9:1915. https://doi.org/10.31661/gmj.v9i0.1915. 
10. Moriguchi T, Harii N, Goto J, Harada D, Sugawara H, Takamino J, et al. A first case of meningitis/encephalitis associated with SARS-coronavirus-2. Int J Infect Dis. 2020;94:55-8. https://doi.org/10.1016/j.jijid.2020.03.062.

11. Falcone MM, Rong AJ, Salazar H, Redick DW, Falcone S, Cavuoto KM. Acute abducens nerve palsy in a patient with the novel coronavirus disease (COVID-19). J AAPOS. 2020;24(4):216-7. https://doi.org/10.1016/j.jaapos.2020. 06.001.

12. Novi G, Rossi T, Pedemonte E, Saitta L, Rolla C, Roccatagliata L, et al. Acute disseminated encephalomyelitis after SARS-CoV-2 infection. Neurol Neuroimmunol Neuroinflamm. 2020;7(5):e797. https://doi.org/10.1212/NXI. 0000000000000797.

13. AlKetbi R, AlNuaimi D, AlMulla M, AlTalai N, Samir M, Kumar N, et al. Acute myelitis as a neurological complication of Covid-19: a case report and MRI findings. Radiology Case Reports. 2020;15(9):1591-5.

14. Pfefferkorn T, Dabitz R, von Wernitz-Keibel T, Aufenanger J, Nowak-Machen M, Janssen $\mathrm{H}$. Acute polyradiculoneuritis with locked-in syndrome in a patient with Covid-19. J Neurol. 2020;267(7):1883-4. https://doi.org/10.1007/ s00415-020-09897-y.

15. Degen C, Lenarz T, Willenborg K. Acute profound sensorineural hearing loss after COVID-19 pneumonia. Mayo Clin Proc. 2020;95(8):1801-3. https://doi. org/10.1016/j.mayocp.2020.05.034.

16. Haddadi K, Ghasemian R, Shafizad M. Basal ganglia involvement and altered mental status: a unique neurological manifestation of coronavirus disease 2019. Cureus. 2020;12(4):e7869. https://doi.org/10.7759/cureus.7869.

17. Bonardel C, Bonnerot M, Ludwig M, Vadot W, Beaune G, Chanzy B, et al. Bilateral posterior cerebral artery territory infarction in a SARS-Cov-2 infected patient: discussion about an unusual case. Journal of Stroke and Cerebrovascular Diseases. 2020;29(9):105095. https://doi.org/10.1016/j. jstrokecerebrovasdis.2020.105095.

18. Oliveira RdMC d, Santos DH, Olivetti BC, Takahashi JT. Bilateral trochlear nerve palsy due to cerebral vasculitis related to covid-19 infection. Arquivos de NeuroPsiquiatria. 2020;78(7):385-6. https://doi.org/10.1590/0004-282×20200052.

19. Shoskes A, Migdady I, Fernandez A, Ruggieri P, Rae-Grant A. Cerebral microhemorrhage and purpuric rash in COVID-19: the case for a secondary microangiopathy. J Stroke Cerebrovasc Dis. 2020;29(10):105111. https://doi. org/10.1016/j.jstrokecerebrovasdis.2020.105111.

20. Vaschetto R, Cena T, Sainaghi PP, Meneghetti G, Bazzano S, Vecchio D, et al. Cerebral nervous system vasculitis in a Covid-19 patient with pneumonia. J Clin Neurosci. 2020;79:71-3. https://doi.org/10.1016/j.jocn.2020.07.032.

21. Klein DE, Libman R, Kirsch C, Arora R. Cerebral venous thrombosis: a typical presentation of COVID-19 in the young. J Stroke Cerebrovasc Dis. 2020;29(8): 104989. https://doi.org/10.1016/j.jstrokecerebrovasdis.2020.104989.

22. Tun CA, UnlUba SY, Alemdar M, AkyUz E. Coexistence of COVID-19 and acute ischemic stroke report of four cases. J Clin Neurosci. 2020;77:227-9.

23. Yin R, Feng W, Wang T, Chen G, Wu T, Chen D, et al. Concomitant neurological symptoms observed in a patient diagnosed with coronavirus disease 2019. J Med Virol. 2020;92(10):1782-4. https://doi.org/10.1002/jmv.25888.

24. Scullen T, Keen J, Mathkour M, Dumont AS, Kahn L. Coronavirus 2019 (COVID-19)-associated encephalopathies and cerebrovascular disease: the New Orleans experience. World Neurosurg. 2020;141:e437-e46. https://doi. org/10.1016/j.wneu.2020.05.192

25. Avula A, Nalleballe K, Narula N, Sapozhnikov S, Dandu V, Toom S, et al. COVID-19 presenting as stroke. Brain, Behavior, and Immunity. 2020;87:1159. https://doi.org/10.1016/j.bbi.2020.04.077.

26. Sohal S, Mansur M. COVID-19 presenting with seizures. IDCases. 2020;20: e00782. https://doi.org/10.1016/j.idcr.2020.e00782.

27. Jain $R$, Young $M$, Dogra $S$, Kennedy $H$, Nguyen $V$, Jones $S$, et al. COVID-19 related neuroimaging findings: a signal of thromboembolic complications and a strong prognostic marker of poor patient outcome. J Neurol Sci. 2020;414:116923. https://doi.org/10.1016/j.jns.2020.116923.

28. Sirous R, Taghvaei R, Hellinger JC, Krauthamer AV, Mirfendereski S. COVID19-associated encephalopathy with fulminant cerebral vasoconstriction: CT and MRI findings. Radiol Case Rep. 2020;15(11):2208-12. https://doi.org/10.1 016/j.radcr.2020.08.024

29. Al Mazrouei SS, Saeed GA, Al Helali AA, Ahmed M. COVID-19-associated encephalopathy: neurological manifestation of COVID-19. Radiol Case Rep. 2020;15(9):1646-9. https://doi.org/10.1016/j.radcr.2020.07.009.

30. Pascual-Goni E, Fortea J, Martinez-Domeno A, Rabella N, Tecame M, GomezOliva C, et al. COVID-19-associated ophthalmoparesis and hypothalamic involvement. Neurol Neuroimmunol Neuroinflamm. 2020;7(5):e823. https:/ doi.org/10.1212/NXI.0000000000000823.
31. Gill I, Chan S, Fitzpatrick D. COVID-19-associated pulmonary and cerebral thromboembolic disease. Radiol Case Rep. 2020;15(8):1242-9. https://doi. org/10.1016/j.radcr.2020.05.034.

32. Dixon L, Varley J, Gontsarova A, Mallon D, Tona F, Muir D, et al. COVID-19related acute necrotizing encephalopathy with brain stem involvement in a patient with aplastic anemia. Neurol Neuroimmunol Neuroinflamm. 2020; 7(5):e789. https://doi.org/10.1212/NXI.0000000000000789.

33. Ashrafi F, Zali A, Ommi D, Salari M, Fatemi A, Arab-Ahmadi M, et al. COVID19-related strokes in adults below 55 years of age: a case series. Neurol Sci. 2020;41(8):1985-9. https://doi.org/10.1007/s10072-020-04521-3.

34. Efe IE, Aydin OU, Alabulut A, Celik O, Aydin K. COVID-19-associated encephalitis mimicking glial tumor. World Neurosurg. 2020;140:46-8. https:// doi.org/10.1016/j.wneu.2020.05.194

35. Somani S, Pati S, Gaston T, Chitlangia A, Agnihotri S. De novo status epilepticus in patients with COVID-19. Ann Clin Transl Neurol. 2020;7(7): 1240-4. https://doi.org/10.1002/acn3.51071.

36. Hosseini AA, Shetty AK, Sprigg N, Auer DP, Constantinescu CS. Delirium as a presenting feature in COVID-19: neuroinvasive infection or autoimmune encephalopathy? Brain Behav Immun. 2020;88:68-70. https://doi.org/10.101 6/j.bbi.2020.06.012.

37. Haddad S, Tayyar R, Risch L, Churchill G, Fares E, Choe M, et al. Encephalopathy and seizure activity in a COVID-19 well controlled HIV patient. IDCases. 2020;21:e00814. https://doi.org/10.1016/j.idcr.2020.e00814.

38. Zhang H, Charmchi Z, Seidman RJ, Anziska Y, Velayudhan V, Perk J. COVID19-associated myositis with severe proximal and bulbar weakness. Muscle Nerve. 2020;62(3):E57-60. https://doi.org/10.1002/mus.27003.

39. Afshar H, Yassin Z, Kalantari S, Aloosh O, Lotfi T, Moghaddasi M, et al. Evolution and resolution of brain involvement associated with SARS- CoV2 infection: a close clinical - paraclinical follow up study of a case. Mult Scler Relat Disord. 2020;43:102216. https://doi.org/10.1016/j.msard.2020.102216.

40. Elgamasy S, Kamel MG, Ghozy S, Khalil A, Morra ME, Islam SMS. First case of focal epilepsy associated with SARS-coronavirus-2. J Med Virol. 2020;92(10): 2238-42. https://doi.org/10.1002/jmv.26113.

41. Domingues RB, Mendes-Correa MC, de Moura Leite FBV, Sabino EC, Salarini DZ, Claro I, et al. First case of SARS-COV-2 sequencing in cerebrospinal fluid of a patient with suspected demyelinating disease. J Neurol. 2020;267(11): 3154-6. https://doi.org/10.1007/s00415-020-09996-w.

42. Fasano A, Cavallieri F, Canali E, Valzania F. First motor seizure as presenting symptom of SARS-CoV-2 infection. Neurol Sci. 2020;41(7):1651-3. https://doi. org/10.1007/s10072-020-04460-z.

43. De Stefano P, Nencha U, De Stefano L, Megevand P, Seeck M. Focal EEG changes indicating critical illness associated cerebral microbleeds in a Covid-19 patient. Clin Neurophysiol Pract. 2020;5:125-9. https://doi.org/10.1 016/j.cnp.2020.05.004.

44. van den Enden AJM, van Gils L, Labout JAM, van der Jagt M, Moudrous W. Fulminant cerebral edema as a lethal manifestation of COVID-19. Radiol Case Rep. 2020;15(9):1705-8. https://doi.org/10.1016/j.ra dcr.2020.06.053

45. Khattar NK, Sharma M, McCallum AP, Oxford BG, Zeb H, Suliman SA, et al. Intracranial hemorrhage in a young COVID-19 patient. Interdiscip Neurosurg. 2020;22:100878. https://doi.org/10.1016/j.inat.2020.100878.

46. Sharifi-Razavi A, Karimi N, Zarvani A, Cheraghmakani H, Baghbanian SM. Ischemic stroke associated with novel coronavirus 2019: a report of three cases. Int J Neurosci. 2020:1-5. https://doi.org/10.1080/00207454.2 020.1782902 .

47. Avula A, Gill A, Nassar R, Nalleballe K, Siddamreddy S, Chalhoub M. Lockedin with COVID-19. J Clin Neurosci. 2020;79:80-3. https://doi.org/10.1016/j. jocn.2020.07.014.

48. Fara MG, Stein LK, Skliut M, Morgello S, Fifi JT, Dhamoon MS. Macrothrombosis and stroke in patients with mild Covid-19 infection. J Thromb Haemost. 2020;18(8):2031-3. https://doi.org/10.1111/jth.14938.

49. Patel SD, Kollar R, Troy P, Song X, Khaled M, Parra A, et al. Malignant cerebral ischemia in a COVID-19 infected patient: case review and histopathological findings. J Stroke Cerebrovasc Dis. 2020;29(11):105231. https://doi.org/10.1016/j.jstrokecerebrovasdis.2020.105231.

50. Palao M, Fernandez-Diaz E, Gracia-Gil J, Romero-Sanchez CM, Diaz-Maroto I, Segura T. Multiple sclerosis following SARS-CoV-2 infection. Mult Scler Relat Disord. 2020;45:102377. https://doi.org/10.1016/j.msard.2020.102377.

51. Mohammad LM, Botros JA, Chohan MO. Necessity of brain imaging in COVID19 infected patients presenting with acute neurological deficits. Interdiscip Neurosurg. 2020;22:100883. https://doi.org/10.1016/j.inat.2020.100883. 
52. Siepmann T, Kitzler HH, Lueck C, Platzek I, Reichmann H, Barlinn K. Neuralgic amyotrophy following infection with SARS-CoV-2. Muscle Nerve. 2020;62(4): E68-70. https://doi.org/10.1002/mus.27035.

53. Fan S, Xiao M, Han F, Xia P, Bai X, Chen H, et al. Neurological manifestations in critically ill patients with COVID-19: a retrospective study. Front Neurol. 2020;11:806. https://doi.org/10.3389/fneur.2020.00806

54. Rana S, Lima AA, Chandra R, Valeriano J, Desai T, Freiberg W, et al. Novel coronavirus (COVID-19)-associated Guillain-Barre syndrome: case report. J Clin Neuromuscul Dis. 2020;21(4):240-2. https://doi.org/10.1097/CND. 0000000000000309.

55. Thu SS, Matin N, Levine SR. Olfactory gyrus intracerebral hemorrhage in a patient with COVID-19 infection. J Clin Neurosci. 2020;79:275-6. https://doi org/10.1016/j.jocn.2020.07.033.

56. Le Guennec L, Devianne J, Jalin L, Cao A, Galanaud D, Navarro V, et al. Orbitofrontal involvement in a neuroCOVID-19 patient. Epilepsia. 2020;61(8): e90-4. https://doi.org/10.1111/epi.16612.

57. Rogg J, Baker A, Tung G. Posterior reversible encephalopathy syndrome (PRES): another imaging manifestation of COVID-19. Interdiscip Neurosurg. 2020;22:100808. https://doi.org/10.1016/j.inat.2020.100808.

58. Dakay K, Kaur G, Gulko E, Santarelli J, Bowers C, Mayer SA, et al. Reversible cerebral vasoconstriction syndrome and dissection in the setting of COVID19 infection. J Stroke Cerebrovasc Dis. 2020;29(9):105011. https://doi.org/10.1 016/j.jstrokecerebrovasdis.2020.105011.

59. Princiotta Cariddi L, Tabaee Damavandi P, Carimati F, Banfi P, Clemenzi A, Marelli M, et al. Reversible encephalopathy syndrome (PRES) in a COVID-19 patient. J Neurol. 2020;267(11):3157-60. https://doi.org/10.1007/s00415-02 0-10001-7.

60. Su XW, Palka SV, Rao RR, Chen FS, Brackney CR, Cambi F. SARS-CoV-2associated Guillain-Barre syndrome with dysautonomia. Muscle Nerve. 2020; 62(2):E48-E9. https://doi.org/10.1002/mus.26988.

61. Kimambo H, Chin $\mathrm{H}$, Mnacho M, Punatar P, Msilanga D, Chagula AC. Severe headache as the sole presenting symptom of COVID-19 pneumonia: a case report. Interdiscip Neurosurg. 2020;22:100882. https://doi.org/10.1016/j.inat.2 020.100882 .

62. Pilotto A, Odolini S, Masciocchi S, Comelli A, Volonghi I, Gazzina S, et al. Steroid-responsive encephalitis in coronavirus disease 2019. Ann Neurol. 2020;88(2):423-7. https://doi.org/10.1002/ana.25783.

63. Frisullo G, Bellavia S, Scala I, Piano C, Morosetti R, Brunetti V, et al. Stroke and COVID19: not only a large-vessel disease. J Stroke Cerebrovasc Dis. 2020;29(10):105074. https://doi.org/10.1016/j.jstrokecerebrovasdis.2020.1 05074.

64. Morassi M, Bagatto D, Cobelli M, D’Agostini S, Gigli GL, Bna C, et al. Stroke in patients with SARS-CoV-2 infection: case series. J Neurol. 2020;267(8): 2185-92. https://doi.org/10.1007/s00415-020-09885-2

65. Muccioli L, Rondelli F, Ferri L, Rossini G, Cortelli P, Guarino M. Subcortical myoclonus in COVID-19: comprehensive evaluation of a patient. Mov Disord Clin Pract. 2020;7(8):971-3. https://doi.org/10.1002/mdc3.13046.

66. Rudilosso S, Esteller D, Urra X, Chamorro A. Thalamic perforating artery stroke on computed tomography perfusion in a patient with coronavirus disease 2019. J Stroke Cerebrovasc Dis. 2020;29(8):104974. https://doi.org/1 0.1016/j.jstrokecerebrovasdis.2020.104974.

67. Bernard-Valnet R, Pizzarotti B, Anichini A, Demars Y, Russo E, Schmidhauser $\mathrm{M}$, et al. Two patients with acute meningoencephalitis concomitant with SARS-CoV-2 infection. Eur J Neurol. 2020;27(9):e43-4. https://doi.org/1 $0.1111 /$ ene. 14298 .

68. Fitsiori A, Pugin D, Thieffry C, Lalive P, Vargas MI. COVID-19 is associated with an unusual pattern of brain microbleeds in critically ill patients. J Neuroimaging. 2020;30(5):593-7. https://doi.org/10.1111/jon.12755.

69. Doobay MF, Talman LS, Obr TD, Tian X, Davisson RL, Lazartigues E. Differential expression of neuronal ACE2 in transgenic mice with overexpression of the brain renin-angiotensin system. Am J Physiol Regul Integr Comp Physiol. 2007;292(1):R373-81. https://doi.org/10.1152/ajpregu. 00292.2006

70. Zheng YY, Ma YT, Zhang JY, Xie X. COVID-19 and the cardiovascular system. Nat Rev Cardiol. 2020;17(5):259-60. https://doi.org/10.1038/s41569-020-0360-5.

71. Abboud H, Abboud FZ, Kharbouch H, Arkha Y, El Abbadi N, El Ouahabi A. COVID-19 and SARS-Cov-2 infection: pathophysiology and clinical effects on the nervous system. World Neurosurg. 2020;140:49-53. https://doi.org/10.1 016/j.wneu.2020.05.193.

72. Katal S, Balakrishnan S, Gholamrezanezhad A. Neuroimaging and neurologic findings in COVID-19 and other coronavirus infections: a systematic review in 116 patients. J Neuroradiol. 2021;48(1):43-50. https://doi.org/10.1016/j. neurad.2020.06.007.

73. Netland J, Meyerholz DK, Moore S, Cassell M, Perlman S. Severe acute respiratory syndrome coronavirus infection causes neuronal death in the absence of encephalitis in mice transgenic for human ACE2. J Virol. 2008; 82(15):7264-75. https://doi.org/10.1128/JVI.00737-08.

74. Yavarpour-Bali H, Ghasemi-Kasman M. Update on neurological manifestations of COVID-19. Life Sci. 2020;257:1 18063. https://doi.org/10.101 6/j.lfs.2020.118063.

75. Li K, Wohlford-Lenane C, Perlman S, Zhao J, Jewell AK, Reznikov LR, et al. Middle East respiratory syndrome coronavirus causes multiple organ damage and lethal disease in mice transgenic for human dipeptidyl peptidase 4. J Infect Dis. 2016;213(5):712-22. https://doi.org/10.1093/infdis/ jiv499.

76. Das M, Penn C, Martinez T, Mayilsamy K, McGill A, Wiling A, et al. COVID-19 neurotropism and implications for therapy. Neuroimmunology and Neuroinflammation. 2020;2020(2):141-9.

77. Fridman S, Bullrich MB, Jimenez-Ruiz A, Costantini P, Shah P, Just $C$, et al. Stroke risk, phenotypes, and death in COVID-19: systematic review and newly reported cases. Neurology. 2020;95(24):e3373-85. https://doi.org/1 0.1212/WNL.0000000000010851.

78. Gulko E, Oleksk ML, Gomes W, Ali S, Mehta H, Overby P, et al. MRI brain findings in 126 patients with COVID-19: initial observations from a descriptive literature review. AJNR Am J Neuroradiol. 2020:41(12):2199-203. https://doi.org/10.3174/ajnr.A6805.

79. Pan S, Chen WC, Baal JD, Sugrue LP. Neuroradiological features of mild and severe SARS-CoV-2 infection. Acad Radiol. 2020;27(11):1507-14. https://doi. org/10.1016/j.acra.2020.08.026.

80. Nepal G, Rehrig JH, Shrestha GS, Shing YK, Yadav JK, Ojha R, et al. Neurological manifestations of COVID-19: a systematic review. Crit Care. 2020;24(1):421. https://doi.org/10.1186/s13054-020-03121-z.

81. Templeton SP, Kim TS, O'Malley K, Perlman S. Maturation and localization of macrophages and microglia during infection with a neurotropic murine coronavirus. Brain Pathol. 2008;18(1):40-51. https://doi.org/10.1111/j.1750-3 639.2007.00098.x

82. Lee SG, Fralick M, Sholzberg M. Coagulopathy associated with COVID-19. CMAJ. 2020;192(21):E583. https://doi.org/10.1503/cmaj.200685.

83. Spence JD, de Freitas GR, Pettigrew LC, Ay H, Liebeskind DS, Kase CS, et al. Mechanisms of stroke in COVID-19. Cerebrovasc Dis. 2020:49(4):451-8. https://doi.org/10.1159/000509581.

\section{Publisher's Note}

Springer Nature remains neutral with regard to jurisdictional claims in published maps and institutional affiliations.

\section{Submit your manuscript to a SpringerOpen ${ }^{\circ}$ journal and benefit from:}

- Convenient online submission

- Rigorous peer review

- Open access: articles freely available online

High visibility within the field

- Retaining the copyright to your article

Submit your next manuscript at $>$ springeropen.com 